\title{
The Effect of POWER and 3-2-1 Teaching Strategies and Learning Style on Students' Writing Achievement
}

\author{
Susiasih \\ English Applied Linguistics Study Program Postgraduate \\ Universitas Negeri Medan \\ Medan, Sumatera Utara, 20371, Indonesia \\ saya.susiasih@gmail.com \\ Rahmad Husein \\ English Applied Linguistics Study Program Postgraduate \\ Universitas Negeri Medan \\ Medan, Sumatera Utara 20371, Indonesia \\ rhnapitupulu@yahoo.com \\ I Wayan Dirgeyasa \\ English Applied Linguistics Study Program Postgraduate \\ Universitas Negeri Medan \\ Medan, Sumatera Utara 20371, Indonesia \\ wayandirgeyasa@yahoo.com
}

\begin{abstract}
Writing is a productive skill, where the students should produce a product in written form. Teaching writing cannot stand alone to improve the students writing achievement. It should be integrated with students' style in learning. This research tries to find out whether the students' writing achievement taught by using POWER strategy is significantly higher than 3 -2-1 strategy, whether the students with Read/Write learning style is higher than Kinesthetic learning style in writing achievement, and whether there is a significant interaction between teaching strategies and learning style on the students' writing achievement. This research will be useful to improve the students' skill and writing. The purpose of teaching POWER strategy is to provide explicit instruction to students on how to write, in this example, an effective factual paragraph, keeping in mind the characteristics of students with writing difficulties and the principles of effective instruction. There are many strategies offered by the experts but POWER strategy can be another alternative strategy in improving their teaching skill in writing especially in writing narrative paragraph. The POWER strategy is the independent variable and the writing achievement is the dependent variable. The test instrument of writing paragraph test will be used to collect the data about the students' achievement in writing paragraph. In this research, the researcher will also use writing pre-test and post-test. The pretest and post-test is used to find out the significant differences before and after giving the treatment In analyzing the data, the researcher uses descriptive statistic and inferential statistic technique. The research results found that the students with POWER strategy are higher in writing achievement.
\end{abstract}

Keyword: POWER Strategy, 3-2-1 Strategy, Learning Style, Writing

\section{INTRODUCTION}

\subsection{Background of the Study}

Writing is one of the most important aspects in English language acquisition. It is a phenomenon invented by humans to help in the communication process. Writing also is one of the language skills which used to communicate indirectly, without having face to face with other people. It has become indeed, a social and cultural practice in most societies today. Writing skills are an important part of communication. Writing is a productive skill, where the students should produce a product in written form. It is also a basic level in language proficiency, so that in writing learners should be able to mix several components of language such as vocabulary, spelling and punctuations.

\section{LITERATURE REVIEW}

The writing strategy using Prepare, Organise, Write, Edit Rewrite (POWER) as NSW Department of Education and Training (2007: 95) said that the purpose of teaching POWER strategy is to provide explicit instruction to students on how to write, in this example, an effective factual paragraph, keeping in mind the characteristics of students with writing difficulties and the principles of effective instruction. This research tries to find out whether the students' writing achievement taught by using POWER 
strategy is significantly high. This research will be useful to improve the students' skill and writing. The purpose of teaching strategy is to provide explicit instruction to students on how to write, in this example, an effective factual paragraph, keeping in mind the characteristics of students with writing difficulties and the principles of effective instruction.

\subsection{The Reasons choosing the topic}

Based on the researcher's preliminary research by interview with the teachers and students in Sekolah Menegah Kejuruan Negeri (SMKN) 1 Kutalimbaru, there are a number of crucial issues concerning the teaching and learning of writing. First, the problem came from the students. They only get less information about a topic from particular hand book, so that when they are asked to compose a text they can get idea easily, but difficult to explore it into correct components of the text. For example they only compose a text by determining a topic but when they come into supporting sentences, they do not have any idea, it caused the students stop their composing activity.

Several problems also occur when the teachers have big classes to teach and the result of teaching writing to the students may be defeated. In this case, time also being a big challenge for the teachers to have the students' writing improves because to accomplish a good composition in English, it needs complex steps such as brainstorming, prewriting, drafting, and editing. However, new strategies in teaching writing are needed to develop the students' writing outcomes.

\subsection{Related Researchers}

In doing this research, the writer read some related researches in different journals. In this study, the writer read the journals that related about 3-2-1 strategy, POWER strategy, writing achievement, learning styles and VARK learning styles.

Some researchers conducted the 3-2-1 strategy in recent years. Alsamadani (2011) studied about The Effects of the 3-2-1 Reading Strategy on EFL Reading Comprehension. He tested the King Abdul-Aziz University (KAU) students. Students of both groups took a reading comprehension test at the beginning of the 2010 academic year. The researcher used the 3-2-1 strategy when teaching the experimental group for six weeks whereas the students in the control group were not trained on the strategy. Students were matched according to their reading proficiency, taught by the same teacher (the researcher), and were similar in age. After six weeks of instruction, both groups completed the same reading comprehension test again. The study concludes with recommendations for training EFL students and teachers on using different comprehension strategies, especially those that have proven to be effective in boosting reading comprehension such as the 3-2-1 strategy.

Another researcher was Marlini (2013) in Teaching Reading Comprehension by Using 3-2-1 Strategy To the Tenth Grade Students of SMA Ethika Palembang. In her research she found that 3-2-1 strategy gives a significant difference on students' reading achievement at tenth grade students of SMA Ethika Palembang. Therefore, the writer recommended that 3-2-1 strategy should be used by the teachers of English at SMA Ethika Palembang in teaching reading comprehension.

\section{RESEARCH METHODOLOGY}

\subsection{Research Method}

This research will be conducted by applying a quantitative research with an experimental design with a $2 \mathrm{x}$ 2 factorial design. The reasons to choose this design are: (1) to prove the hypotheses in one experiment and (2) to recognize the interaction between the dependent and independent variables. According to Ary (2010: 310) factorial design is one in which the researcher manipulates two or more variables simultaneously in order to study the independent effect of each variable on the dependent variable, as well as the effects caused by interactions among the several variables. The research is an experimental research by using POWER strategy and learning styles which in this study is only Read/Write and Kinesthetic. Factorial design will be used to investigate the teacher's treatment that will increase the students' writing skill.

\subsection{Populations and Sample}

The population of this research will be 2016/2017 of the second year students of SMKN 1 Kutalimbaru, Pasar IX Kutalimbaru - Sawit Rejo Kec. KutaIimbaru Sumatera Utara. There are 11 classes that consist of 2 TKR (Teknik Kenderaan Ringan) classes, 2 TSM (Teknik Sepeda Motor) classes, 2 TKJ (Teknik Komputer dan Jaringan) classes, 3 RPL(Rekayasa Perangat Lunak) classes and 1 Mekatronika class. Academically the reason of the writer chose this school is that the school is a vocational school (SMK) which needs more attention and the same rights in the general or public school (SMA). The students of SMK tend to be more active in verbal skill than in writing skills. For that reason, the writer chose this school as the subject of the research.

In this research, cluster sampling will be used. The researcher will select 2 TKJ (Teknik Komputer dan Jaringan) classes as the sample by using lottery to choose the experimental and control groups. There are two classes of TKJ and the total number of the students is 64 students. The researcher took all students as the sample. Each class into two groups. The first group will be applied the POWER strategy and they are an experimental group. The rest students will be applied conventional 1 strategy and they are a control group. After the two groups selected, then the researcher submit the VARK questionnaires. After finding out the models of learning style, then the students will be classified into their learning style models, they are Visual, Aural/Auditory, Read/Write, Kinesthetic and Multimodal. In this research, the researcher took Read/Write, and Kinesthetic styles.

\subsection{Research Variables}

This research has three variables: one independent variable, one moderator variable and one dependent variable. The independent variable is teaching writing 
strategy that is classified into two, POWER and conventional strategies. The moderator variable is learning style which is classified into Read/Write, and Kinesthetic. Meanwhile writing achievement is the dependent variable.

\subsection{Instrument of the Data Collection}

Tomal (2010: 93) defines that the term of instrumentation refers to the method by which data is collected (e.g., survey, observation, or interview). Therefore, the use of instrumentation, in itself, can impact the validity of the data being collected. There are two kinds of instruments in education, they are: (1) Test instruments, and (2) Non-test instrument. In this research, the researcher will use both of the instruments for collecting the data. The test instrument of writing paragraph test will be used to collect the data about the students' achievement in writing paragraph, while the non-test instrument is VARK questionnaire that will be used to collect the data about the students' learning style models.

\subsection{Writing Paragraph Test}

Writing paragraph test is a test instrument used to measure the students' achievement in writing before and after applying the strategies by different groups. The test will be a writing instruction for certain topics. Hogue (2008: 4) defines that a paragraph is a group of related sentences about a single topic. The topic of a paragraph is one, and only one, idea. Moreover, she said that A paragraph has three main parts. (1) Topic sentence. It means that the first sentence in a paragraph is a sentence that names the topic and tells what the paragraph will explain about the topic. (2) Supporting sentences. This means that the middle sentences in a paragraph give examples or other details about the topic, and (3) Concluding sentence. This means that the last sentence in a paragraph often repeats the topic sentence in different words or summarizes the main points.

There are four types of writing paragraph, they are descriptive, narrative, persuasion, and argumentative. The researcher will choose narrative paragraph. Kane (2000: 7) states that the subject of narration is a series of related events - a story. Its problem is twofold: to arrange the events in a sequence of time and to reveal their significance. The reason for choosing narrative paragraph is that in narration, the meaning of a story is truly communicated and has to be rendered in the characters and plot and setting that makes the students easier in expressing their ideas.

In educational research achievement tests are most commonly used. In this research, the test will be administered before and after the researcher treats the students with POWER and conventional strategies. It will be performed to know the significant different of students' writing paragraph achievement before and after treatment. In scoring the students' work, the researcher will use the holistic scoring.

Hyland (2003: 227) said that a holistic scale is based on a single, integrated score of writing behavior. This method aims to rate a writer's overall proficiency through an individual impression of the quality of a writing sample.
This global approach to the text reflects the idea that writing is a single entity which is best captured by a single scale that integrates the inherent qualities of the writing.

\subsection{Questionnaires of Learning Style}

Ary (2003: 648) defines questionnaires as an instrument in which respondents provide written responses to questions or mark items that indicate their responses. Along with this, Singh (2006: 191) said that a questionnaire is a form which is prepared and distributed for the purpose of securing responses. Generally these questions are factual and designed for securing information about certain conditions or practices, of which recipient is presumed to have knowledge. In this research, Questionnaire is a non-test instrument used to collect factual information about the students' style in learning in order to classify the students into Read/Write, and Kinesthetic. The researcher will use the VARK Questionnaire that consists of 16 questions in multiple choice forms. The students will answer the questions, then the result will be calculated based on the VARK Scoring Chart to find the VARK category that each of the students' answers corresponds to.

\subsection{Validity and Reliability of Instrument}

\subsubsection{Validity}

Validity is the most important consideration in developing and evaluating measuring instruments. Ary (2003: 225) defines validity as the extent to which an instrument measured what it claimed to measure. The focus of recent views of validity is not on the instrument itself but on the interpretation and meaning of the scores derived from the instrument. To obtain the validity of writing test, the researcher will use Point biserial correlation that is 1 continuous variable 1 true dichotomy, Interval or ratio scale. The result of the students' achievement in writing narrative after being scored by using rubric scoring, the calculation will be used as Fraenkel and Wallen (2009: 250) suggested.

\subsubsection{Reliability}

Fraenkel and Wallen (2009: 154) said that reliability refers to the consistency of the scores obtained-how consistent they are for each individual from one administration of an instrument to another and from one set of items to another.

\subsubsection{Research Procedure}

In this research there are two groups of students, namely experimental group and control group. The experimental group will be taught by using POWER writing strategy and the control group will be taught by using conventional writing strategy. In order to find out the interaction between writing strategies and learning strategies in writing, the researcher will provide a VARK questionnaire to classify the students based on their style in learning (Read/write, and Kinesthetic). 
In this research, the researcher will also use writing pretest and post-test. The pre-test and post-test is used to find out the significant differences before and after giving the treatment and the score of the pre-test will be used as the preliminary data which draw the students' writing achievement. Meanwhile the post-test will be administered after giving the treatment in both groups. The score of posttest will be the final data which will be analyzed.

\section{RESULT AND DISCUSSION}

\subsection{The Students' Achievement on writing Taught by Using} POWER

The mean score of the students taught by using POWER strategy is 35.68 , the median or the central score is 37.00 , and the standard deviation is 7.56. It is from the maximum score of 47.00 and the minimum or the lowest score is 23.00.

\subsection{The Students' Achievement on writing Taught by Using} 3-2-1

The mean score of the students taught by using 3-2-1 strategy is 29.7667 , the median or the central score is 30.00 , and the standard deviation is 6.905.56. It is from the maximum score of 43.00 and the minimum or the lowest score is 20.00 .

\subsection{The Read/Write Students Achievement on Writing Taught by Using POWER and 3-2-1 Strategies}

The mean score of the Read/Write students that taught by using POWER and 3-2-1 strategies is 35.47 , the median or the central score is 37.00 , the standard deviation is 7.43 . It is from the maximum score of 47.00 and the minimum or the lowest score of 20.00

\subsection{The Kinesthetic Students Achievement on Writing Taught by Using POWER and 3-2-1 Strategies}

The mean score of the Read/Write students that taught by using POWER and 3-2-1 strategies is 29.327, the median or the central score is 27.00 , the standard deviation is 6.35 . It is from the maximum score of 40.00 and the minimum or the lowest score of 20.00 .

\subsection{Hypothesis Testing}

To estimate the effect of teaching strategies (POWER and 3-2-1) and learning style (Read/Write and Kinesthetic) on students' writing and to examine the interaction effect of on teaching strategies and the learning style the researcher used two-way analysis of Variance. The result is as follows:
Table 1. Learning Style and Teaching Strategies Results

\begin{tabular}{|l|l|l|l|}
\hline \multirow{2}{*}{$\begin{array}{c}\text { Learning } \\
\text { Style }\end{array}$} & \multicolumn{2}{|c|}{ Teaching Strategies } & \multirow{2}{*}{ Total } \\
\cline { 2 - 3 } Read/Write & POWER & \multicolumn{1}{|c|}{$\mathbf{3 - 2 - 1}$} & \\
& $\mathrm{N}=21$ & $\mathrm{~N}=15$ & $\mathrm{~N}=36$ \\
& $\mathrm{X}=39.39$ & $\overline{\mathrm{X}}=30.13$ & $\mathrm{X}=69.42$ \\
\hline Kinesthetic & $\mathrm{N}=13$ & $\mathrm{~N}=15$ & $\mathrm{~N}=28$ \\
& $\overline{\mathrm{X}}=28.23$ & $\overline{\mathrm{X}}=29.20$ & $\mathrm{X}=57.43$ \\
\hline Total & $\mathrm{N}=34$ & $\mathrm{~N}=30$ & $\mathrm{~N}=64$ \\
& $\sum \mathrm{X}=1192$ & $\sum \mathrm{X}=890$ & $\sum \mathrm{X}=2082$ \\
& $\sum \mathrm{X}^{2}=$ & $\sum \mathrm{X}^{2}$ & $\sum \mathrm{X}^{2}$ \\
& $\mathbf{8 1 5 3 1 4}$ & 396148 & $\mathbf{1 2} 11462$ \\
& $\overline{\mathrm{X}}=\mathbf{6 7 . 5 2}$ & $\overline{\mathrm{X}}=\mathbf{5 9 . 3 3}$ & $\mathbf{X}=\mathbf{1 2 6 . 8 5}$ \\
\hline
\end{tabular}

4.6 Power strategy is higher than 3-2-1 strategy

POWER and 3-2-1 strategies significantly affect the students' writing achievements. It is proven by the value of $\mathrm{F}_{\text {observed }}=2.51$ at level $0.05, \mathrm{~F}_{\text {table }}=2.00$. Thus $\mathrm{F}_{\text {obsrved }}>$

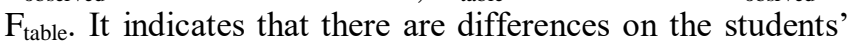
writing achievement significantly between the students taught by using POWER and those taught by using 3-2-1 strategies. Furthermore, writing achievement score mean of the students taught by POWER ( $\mathrm{x}=35.059)$ is higher than those are taught by using 3-2-1 ( $\mathrm{x}=29.667)$. It indicates that POWER strategy is more effective than 3-2-1 strategy.

4.7 Read/Write learning style is higher than Kinesthetic learning style

Learning style significantly and directly affects the students' writing achievement. It is proven by the value of $\mathrm{F}_{\text {observed }}=5.52$ at level $0.05, \mathrm{~F}_{\text {table }}=4.00$. Thus, $\mathrm{F}_{\text {observed }}>$

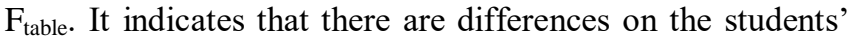
writing achievement significantly between Read/Write and Kinesthetic learning style students. Furthermore, the writing achievement score mean of the Read/Write students (X = $35.472)$ is higher than the Kinesthetic students $(X=28.75)$. It indicates that Read/Write students are more skilled in writing than the kinesthetic students.

4.8 Interaction between Teaching Strategies and Learning Style on the Students' achievement in Writing

The results of this research show that there is a significant interaction between teaching strategies and learning style on the students' writing achievement. So, the students in control group and experimental group would benefit from writing lessons. Teaching strategies and learning style affect the students' writing achievement. Generally POWER is more effective than 3-2-1 but specifically the combination of POWER and Read/Write style is much more effective than the others and 3-2-1 worked better for Kinesthetic style rather than Read/Write style since it tempted the students to compete seriously. 


\section{CONCLUSION}

From the result of the research, some conclusion can be drawn as follows:

1. The students' achievement in writing by using POWER strategy is higher than 3-2-1 strategy,

2. The students with Read/Write learning style is higher than Kinesthetic learning style in writing achievement,

3. There is a significant interaction between teaching strategies and learning style on the students' writing achievement.

\section{ACKNOWLEDGEMENT}

In arranging this paper, a lot of people have provided motivation, advice, and support for the researcher. This paper would not have been possible without the help, support and patience of lecturers, first advisor,Dr.Rahmad Hussein, M.Pd for his supervision, advice, and guidance from the very early stage of this research as well as giving me extraordinary experiences throughout the past few years. Then to second advisor Dr.I Wayan Dirgeyasa, M.Hum who has helped patiently finishing this paper by giving suggestion, guidance, and correction until the completion of this paper.The researcher greatest appreciation also goes to Prof. Dr. Busmin Gurning, M.Pd, Dr. Anni Hollila Pulungan,M.Hum, Dr. Didik Santoso, M.Pd as the examiner.

\section{REFERENCES}

[1] Ary, D. 2010. "Introduction to Research in Education". Eight Edition. Belmont: Wadsworth.

[2] Fraenkel, J.R. and Norman E. W. 2009. "How to Design and Evaluate Research in Education”. Seventh Edition. New York: McGraw-Hill Companies.

[3] Hogue, A. 2008. "First Steps in Academic Writing". Second Edition. New York : Pearson Education, Inc.

[4] Hyland, K. 2003. "Second Language Writing". London: Cambridge University Press.

[5] Kane, T.K. 2000. "The Oxford Guide to Writing”. London: Oxford University Press.

[6] Singh, Y.K. 2006. "Fundamentals of Research Methodology and Statistics". New Delhi: New Age International.

[7] Tomal, D.R. 2010. "Action Research for Educators". Second Edition. London: Rowman \& Littlefield Education. 